\title{
Representasi Matematis Siswa Bina Prestasi MTsN 1 Jember dalam Menyelesaikan Masalah Segiempat Ditinjau dari Level van Hiele
}

Author:
Muhammad Ainul Yaqin
Fiddinil Islam $^{1}$
Sunardi $^{2}$
Reza Ambarwati $^{3}$
Siti Alfiah ${ }^{4}$
Affiliation:
${ }^{1,2,3}$ University of Jember, East
Java, Indonesia
${ }^{4}$ MTs Negeri 1 Jember, East
Java, Indonesia

Corresponding author:
Pramesthya Dwi
Retnaninggalih,
prameshretna76@ gmail.com
Dates:
Received: $25 / 2 / 2021$
Accepted: $7 / 3 / 2021$
Published: $16 / 3 / 2021$

\begin{abstract}
Abstrak. Penelitian ini bertujuan untuk mengetahui representasi matematis Kemampuan Siswa dalam Menyelesaikan Masalah Segi Empat Berdasarkan Tingkatan Van Hiele pada Program Pengayaan di MTsN 1 Jember. Penelitian ini merupakan penelitian kualitatif deskriptif. Subjek penelitian ini adalah 17 siswa kelas IXA di MTsN 1 Jember. Metode pengumpulan data dalam penelitian ini menggunakan metode tes dan wawancara. Instrumen tes dalam penelitian ini berupa tes kemampuan berpikir geometri dan tes representasi matematis pada materi persegi panjang. Hasil analisis data dilakukan dengan membandingkan hasil tes representasi matematis dengan wawancara, kemudian dikategorikan berdasarkan tingkat berpikir Van Hiele dari hasil tes kemampuan berpikir geometris. Hasil penelitian menunjukkan bahwa siswa dengan tingkat berpikir visual memiliki kecenderungan menggunakan representasi simbolik dan verbal dalam menyelesaikan masalah. Siswa dengan tingkat berpikir analitik cenderung menggunakan representasi verbal, visual, dan simbolik dalam menyelesaikan masalah
\end{abstract}

Kata kunci: Representasi Matematika, Segi Empat, Siswa Berprestasi Tinggi, Level Van Hiele

\begin{abstract}
This study aims to determine mathematical representation of Students' Ability in Solving Quadrilateral Problems Based on Van Hiele's Levels at an Enrichment Program in MTsN 1 Jember. This research is a descriptive qualitative research. The subjects of this study were 17 students of class IXA at MTsN 1 Jember. The data collection method on this research are using test and interview methods. The test instrument on this research were a test of ability to think geometry and a test of mathematical representation on rectangular material. The results of data analysis were carried out by comparing the results of the mathematical representation test with interviews, then categorized based on Van Hiele's level of thinking from the results of the geometric thinking ability test. The results showed that students with a visual thinking level had a tendency to use symbolic and verbal representations in solving problems. Students with the analytical thinking level tend to use verbal, visual, and symbolic representations in solving problems.
\end{abstract}

Keywords: Mathematical Representation, Quadrilateral, High Achiever Student, Van Hiele levels

\section{JoMEaL}

Copyright:

This work is licensed under a Creative Commons Attribution-ShareAlike 4.0 International License.

Read online:

https://jurnal.unej.ac.id/index.php/JOMEAL/index or scan barcode beside.

How to cite this article:

Islam, M., Sunardi, S., Ambarwati, R., \& Alfiah, S. (2021). Representasi Matematis Siswa Bina Prestasi MTsN 1 Jember dalam Menyelesaikan Masalah Segiempat Ditinjau dari Level van Hiele. Journal of Mathematics Education and Learning, 1(1), 27-37. Retrieved from https://jurnal.unej.ac.id/index.php/JOMEAL/article/view/24373 


\section{Pendahuluan}

Matematika merupakan salah satu bidang keilmuan yang ada di kurikulum sekolah dan perlu dikuasai oleh siswa. Pembelajaran matematika merupakan situasi dan kondisi belajar mengajar yang diciptakan oleh guru untuk mengembangkan dan mengkonstruksi pemahaman matematika bagi siswa (Amir \& Risnawati, 2015). Pemahaman matematika yang dikembangkan oleh guru pada siswa, hendaknya merujuk kepada fungsi matematika yaitu sebagai instrumen, alat berpikir, dan ilmu pengetahuan untuk menyelesaikan masalah. Oleh sebab itu, untuk mencapai kegiatan belajar mengajar yang baik, maka seluruh siswa harus aktif dalam kegiatan belajar mengajar matematika. Siswa yang aktif di kelas dapat ditunjukkan dengan kegiatan memberikan pendapat, mengajukan pertanyaan, ataupun terlibat dalam diskusi sebuah topik (Safrida, Ambarwati, \& Albirri, 2017).

Cabang ilmu matematika yang memungkinkan ide-ide pemecahan masalah dapat digambar adalah geometri. Masalah-masalah yang berkaitan dengan geometri sangat dekat terhadap aktivitas sehari-hari. Sehingga geometri mendapat posisi yang cukup penting dalam kurikulum pendidikan (Gafur, Ismaimuza, \& Puluhulawa, 2016). Pentingnya geometri dipelajari oleh siswa disebabkan karena kemampuan geometri masih tegolong rendah. Mudzakkir (dalam Armadan dkk., 2017) mengutip hasil penelitian The Third International Mathematics and Science Study yang menyatakan bahwa kemampuan representasi ide pelajar SMP di Indonesia dalam materi aljabar, pembagian bilangan, representasi data, geometri, peluang dan analisis masih tergolong rendah.

Segiempat merupakan salah satu pokok bahasan yang ada dalam pembelajaran matematika. Wagiyo (dalam Siswoyo, 2012) menjelaskan bahwa segiempat merupakan sebuah bangun datar yang terbentuk oleh empat titik dan dihubungkan oleh masing-masing garis yang bertemu dari setiap 2 titik. Garis-garis yang menghubungkan dua titik pada bangun segiempat disebut sisi-sisi segiempat (Nadjib, 2014).

Kemampuan representasi merupakan salah satu standar keterampilan proses berpikir. NCTM menetapkan beberapa standar keterampilan proses berpikir siswa yaitu: a) Pemecahan; b) Penalaran; c) Komunikasi; d) Koneksi; dan e) Representasi (NCTM, 2000). Ostad (dalam Kartini, 2009) menjelaskan bahwa representasi matematis digunakan untuk berpikir dan mengkomunikasikan ide atau konsep-konsep matematis dengan model tertentu. Model-model dalam mengkomunikasikan ide atau konsep-konsep matematis berupa simbol matematika, verbal, dan visual.

Hiebert dan Carpenter (dalam Sabirin, 2014) menjelaskan jika representasi matematis terbagi kedalam dua bentuk, yaitu representasi internal dan eksternal. Representasi internal mencakup konsep-konsep matematis seorang siswa dalam mendorong kemampuan pemecahan masalah. Sedangkan untuk representasi eksternal merupakan kemampuan siswa dalam mengkomunikasikan hasil atau solusi pemecahan masalah dengan menggunakan bentuk simbol, verbal, ataupun secara visual. Oleh karena itu, siswa penting untuk mengetahui model representasi apa yang akan digunakan untuk menyelesaikan sebuah masalah, menghubungkan masing-masing model representasi, dan menyajikannya dalam bentuk representasi simbolik, verbal, ataupun visual.

Teori Van Hiele dikembangkan oleh Pier M. Van Hiele dan Dina Van Hiele di Universitas Utrecht (Yildiz, Aydin, \& Kögce, 2009). Teori Van Hiele mengklasifikasikan kemampuan berpikir geometri menjadi 5 tingkat yang berhubungan satu sama lain (Erdo \& Durmu, 2009). Pengklasifikasian kemampuan berpikir geometri menjadi 5 tingkatan merupakan karakteristik yang utama dalam teori Van Hiele. Setiap tingkatan berpikir memiliki karakteristik tertentu dan menentukan proses berpikir yang penting untuk menyelesaikan masalah geometri. Guven (dalam Y1ldız dkk., 2009) menjelaskan tingkatan-tingkatan berpikir tersebut antara lain: 1) Tingkat 0 (visual); 
2) Tingkat 1 (analisis); 3) Tingkat 2 (deduksi informal); 4) Tingkat 3 (deduksi); dan 5) Tingkat 4 (rigor).

Kelas bina prestasi MTsN 1 Jember merupakan sebuah upaya program pengembangan sekolah untuk meningkatkan kemampuan kognitif, wawasan, dan keterampilan siswa dalam ranah perlombaan maupun olimpiade. Siswa bina prestasi memperoleh waktu belajar yang lebih banyak daripada kelas reguler, sehingga tentunya siswa bina prestasi akan mempunyai tingkatan dan pengalaman berpikir yang lebih tinggi dari siswa kelas reguler. Oleh karena itu, berdasarkan faktafakta yang telah disajikan, perlu dilakukan sebuah analisis representasi matematis siswa bina prestasi MTsN 1 Jember dalam menyelesaikan masalah segiempat berdasarkan tingkatan berpikir oleh Teori Van Hiele. Proses analisis bertujuan untuk mengetahui representasi simbolik, verbal, dan visual dari siswa bina prestasi berdasarkan teori Van Hiele.

\section{Metode Penelitian}

Penelitian ini menggunakan pendekatan kualitatif deskriptif, yang bertujuan untuk mengetahui representasi matematis siswa bina prestasi MTsN 1 Jember dalam menyelesaikan masalah segiempat berdasaran tingkatan berpikir Van Hiele. Variabel pada penelitian ini adalah kemampuan representasi matematis siswa prestasi MTsN 1 Jember berdasarkan tingkatan berpikir Van Hiele. Subjek pada penelitian ini adalah siswa kelas IXA yang berjumlah 17 orang dengan 3 orang laki-laki dan 14 orang perempuan.

Prosedur pada penelitian ini sebagai berikut:

1. Tahap Persiapan

Langkah-langkah yang dilakukan pada tahap persiapan antara lain: a) Pembuatan instrumen penelitian yaitu soal tes representasi matematis materi segiempat dan pedoman wawancara, b) Melakukan validasi instrumen kepada validator. Validator pada penelitian ini adalah dua dosen dari Pendidikan Matematika FKIP Universitas Jember dan 1 guru matematika dari MTsN 1 Jember, c) Menerima hasil validasi dan melakukan revisi hingga instrumen dinyatakan valid oleh validator. Instrumen dinyatakan valid apabila nilai $V_{a} \geq 3$, d) Membuat surat ijin penelitian, e) Berkoordinasi dengan pihak sekolah mengenai jadwal kegiatan penelitian, e) Pihak sekolah membuat surat pemberitahuan kepada kelas IXA.

2. Tahap Pelaksaaan

Pengumpulan data pada penelitian ini dilakukan sebanyak 2 pertemuan. Pengumpulan data pada pertemuan pertama dilakukan secara offline dengan syarat dan ketentuan yang sudah ada pada surat pemberitahuan, misalnya memperhatikan protokol covid-19 dan diperbolehkan ke sekolah oleh orang tua masing-masing. Pada pertemuan pertama, dilakukan pengumpulan data dengan menggunakan tes kemampuan berpikir geometri yang dikutip dari Sunardi (2000) dan tes kemampuan representasi matematis materi segiempat. Tes kemampuan berpikir geometri berbentuk multiple choice sebanyak 25 soal dan diikuti oleh seluruh siswa kelas IXA. Pedoman penskoran untuk tes kemampuan berpikir geometri mengikuti kriteria penskoran yang dikembangkan oleh Usiskin (1982). Subjek kemudian dikategorikan ke dalam masing-masing tingkatan berpikir Van Hiele dan dipilih 2 subjek pada masing-masing tingkatan untuk mengikuti tes kemampuan representasi matematis materi segiempat. Pertemuan kedua dilakukan secara daring dengan kegiatan wawancara hasil pekerjaan subjek.

3. Tahap Analisis Data 
Pada tahap ini, data yang telah dikumpulkan melalui tes kemampuan berpikir geometri dan tes kemampuan representasi materi segiempat dianalisis dan dibandingkan dengan hasil wawancara. Hasil analisis data yaitu mendeskripsikan representasi matematis siswa berdasarkan tingkatan berpikir Van Hiele.

Indikator representasi matematis yang digunakan adalah hasil modifikasi dari Mudzakir (dalam Yudhanegara dan Lestari, 2015) pada tabel berikut.

Tabel 1. Indikator Representasi Matematis

\begin{tabular}{|c|c|c|}
\hline No & Representasi & Indikator \\
\hline 1. & Verbal (teks tertulis) & $\begin{array}{l}\text { (1) Siswa menyusun langkah-langkah penyelesaian sebuah } \\
\text { permasalahan dalam bentuk verbal. } \\
\text { (2) Siswa menggunakan representasi verbal untuk } \\
\text { menyelesaikan permasalahan. } \\
\text { (3) Siswa menyimpulkan solusi dalam bentuk tulisan. }\end{array}$ \\
\hline 2. & $\begin{array}{l}\text { Visual (grafik, diagram, tabel, } \\
\text { ataupun gambar) }\end{array}$ & $\begin{array}{l}\text { (1) Siswa menyajikan kembali data dalam bentuk visual } \\
\text { (berupa grafik, diagram, tabel, ataupun gambar) untuk } \\
\text { membantu menyelesaikan permasalahan. } \\
\text { (2) Siswa menggunakan representasi visual untuk } \\
\text { menyelesaikan masalah matematika. }\end{array}$ \\
\hline 3. & $\begin{array}{l}\text { Simbolik (model matematis atau } \\
\text { simbol-simbol matematika) }\end{array}$ & $\begin{array}{l}\text { (1) Siswa menyusun model atau persamaan matematis dari } \\
\text { sebuah permasalahan. } \\
\text { (2) Siswa menyelesaikan permasalahan yang berkaitan } \\
\text { dengan persamaan matematis. }\end{array}$ \\
\hline
\end{tabular}

\section{Hasil dan Pembahasan}

Total nilai rata-rata setiap aspek $V_{a}$ untuk tes representasi matematis materi segiempat yaitu 3,386 dan pedoman wawancara yaitu 3,55 . Oleh karena nilai $V_{a} \geq 3$, maka instrumen tersebut valid dan dapat digunakan untuk penelitian. Pemilihan subjek pada penelitian ini didasarkan kepada hasil tes kemampuan berpikir geometri. Setelah dilakukan pengkategorian tingkatan berpikir kedalam tingkatan Van Hiele, dipilih 2 subjek pada masing-masing tingkatan berdasarkan rekomendasi dari guru. Berikut siswa yang mewakili masing-masing tingkatan berpikir Van Hiele.

Tabel 2. Subjek Penelitian

\begin{tabular}{|c|c|c|}
\hline Nama & Kode Siswa & Tingkat Berpikir \\
\hline Y.H.K.N & SV1 & Visual \\
\hline B.A.A & SV2 & Visual \\
\hline W.R.S & SA1 & Analisis \\
\hline I.H.A & SA2 & Analisis \\
\hline
\end{tabular}

Selanjutnya, dilakukan tes representasi matematis materi segiempat yang diikuti oleh 4 subjek dari masing-masing perwakilan tingkatan berpikir tersebut. Hasil analisis data tes representasi matematis dibandingkan dengan hasil wawancara terhadap subjek. Berikut tabel representasi yang muncul pada masing-masing subjek penelitian. 
Tabel 3. Representasi Matematis Siswa Tingkat Visual

\begin{tabular}{|c|c|c|c|c|c|c|}
\hline No. & Subjek & $\begin{array}{c}\text { Bentuk } \\
\text { Representasi }\end{array}$ & Indikator & $\begin{array}{c}\text { Soal } \\
\text { Nomor } 1\end{array}$ & $\begin{array}{c}\text { Soal } \\
\text { Nomor } 2\end{array}$ & $\begin{array}{c}\text { Soal } \\
\text { Nomor } 3\end{array}$ \\
\hline \multirow{7}{*}{1.} & \multirow{7}{*}{ SV1 } & \multirow{3}{*}{ Verbal } & $\begin{array}{l}\text { Siswa menyusun langkah- } \\
\text { langkah penyelesaian sebuah } \\
\text { permsalahan dalam bentuk verbal }\end{array}$ & $\checkmark$ & - & $\checkmark$ \\
\hline & & & $\begin{array}{l}\text { Siswa menggunakan representasi } \\
\text { verbal untuk menyelesaikan } \\
\text { permasalahan }\end{array}$ & $\checkmark$ & - & $\checkmark$ \\
\hline & & & $\begin{array}{l}\text { Siswa menyimpulkan solusi } \\
\text { dalam bentuk tulisan }\end{array}$ & - & - & $\checkmark$ \\
\hline & & \multirow[t]{2}{*}{ Visual } & $\begin{array}{l}\text { Siswa menyajikan kembali data } \\
\text { dalam bentuk visual (berupa } \\
\text { grafik, diagram, tabel, ataupun } \\
\text { gambar) untuk membantu } \\
\text { menyelesaikan permasalahan }\end{array}$ & - & - & - \\
\hline & & & $\begin{array}{l}\text { Siswa menggunakan representasi } \\
\text { visual untuk menyelesaikan dan } \\
\text { menyimpulkan solusi dari } \\
\text { masalah matematika }\end{array}$ & $\checkmark$ & - & $\checkmark$ \\
\hline & & \multirow{2}{*}{ Simbolik } & $\begin{array}{l}\text { Siswa menyusun model atau } \\
\text { persamaan matematis dari sebuah } \\
\text { permasalahan }\end{array}$ & $\checkmark$ & - & $\checkmark$ \\
\hline & & & $\begin{array}{l}\text { Siswa menyelesaikan } \\
\text { permasalahan yang berkaitan } \\
\text { dengan persamaan matematis }\end{array}$ & - & - & $\checkmark$ \\
\hline \multirow{7}{*}{2.} & \multirow{7}{*}{ SV2 } & \multirow{3}{*}{ Verbal } & $\begin{array}{l}\text { Siswa menyusun langkah- } \\
\text { langkah penyelesaian sebuah } \\
\text { permsalahan dalam bentuk verbal }\end{array}$ & $\checkmark$ & - & $\checkmark$ \\
\hline & & & $\begin{array}{l}\text { Siswa menggunakan representasi } \\
\text { verbal untuk menyelesaikan } \\
\text { permasalahan }\end{array}$ & - & - & $\checkmark$ \\
\hline & & & $\begin{array}{l}\text { Siswa menyimpulkan solusi } \\
\text { dalam bentuk tulisan }\end{array}$ & - & - & $\checkmark$ \\
\hline & & \multirow[t]{2}{*}{ Visual } & $\begin{array}{l}\text { Siswa menyajikan kembali data } \\
\text { dalam bentuk visual (berupa } \\
\text { grafik, diagram, tabel, ataupun } \\
\text { gambar) untuk membantu } \\
\text { menyelesaikan permasalahan }\end{array}$ & - & - & $\checkmark$ \\
\hline & & & $\begin{array}{l}\text { Siswa menggunakan representasi } \\
\text { visual untuk menyelesaikan dan } \\
\text { menyimpulkan solusi dari } \\
\text { masalah matematika }\end{array}$ & - & - & $\checkmark$ \\
\hline & & \multirow{2}{*}{ Simbolik } & $\begin{array}{l}\text { Siswa menyusun model atau } \\
\text { persamaan matematis dari sebuah } \\
\text { permasalahan }\end{array}$ & - & - & $\checkmark$ \\
\hline & & & $\begin{array}{l}\text { Siswa menyelesaikan } \\
\text { permasalahan yang berkaitan } \\
\text { dengan persamaan matematis }\end{array}$ & - & - & $\checkmark$ \\
\hline
\end{tabular}

Berdasarkan rangkuman hasil analisis bentuk representasi matematis yang ditampilkan oleh siswa visual pada tabel diatas, diperoleh kesimpulan jika siswa tingkat visual cenderung menggunakan representasi verbal dan simbolik dalam mengerjakan soal berdasarkan tabel indikator 
representasi matematis diatas. Representasi verbal yang ditampilkan oleh siswa visual misalnya siswa tingkat visual mampu menyusun langkah-langkah penyelesaian soal. Langkah-langkah penyelesaian meliputi siswa dapat menuliskan informasi yang diketahui, apa yang ditanyakan oleh soal, dan langkah-langkah penyelesaian. Akan tetapi, siswa tingkat visual masih belum bisa menyimpulkan solusi dari sebuah soal. Hal ini disebabkan karena siswa tingkat visual kurang bisa menyajikan data ke dalam bentuk gambar, sehingga menghambat siswa dalam menuliskan langkah-langkah penyelesaian. Representasi visual yang ditampilkan oleh siswa visual misalnya menyajikan data ke dalam bentuk gambar. Gambar yang disajikan masih sederhana dan tidak diikuti oleh sifat-sifat bangun geoemetri. Apabila diikuti oleh sifat-sifat bangun geometri, misalnya pada soal nomor 1, maka siswa kurang tepat dalam menyajikan gambar. Selanjutnya, representasi simbolik yang ditampilkan siswa tingkat visual misalnya siswa menyusun model atau persamaan matematis sebuah luas bangun untuk menyelesaikan soal. Dalam menggunakan model atau persamaan matematis, siswa tingkat visual bergantung sekali gambar yang disajikan. Apabila gambar tersebut belum pernah diketahui model atau persamaan untuk mencari luasannya, maka siswa tingkat visual tidak bisa menyelesaikan soal. Misalnya pada soal nomor 2, siswa tingkat visual tidak dapat merepresentasikan data ke dalam bentuk gambar, sehingga soal nomor 2 tidak dapat terselesaikan.

Tabel 4. Representasi Matematis Siswa Tingkat Analisis

\begin{tabular}{|c|c|c|c|c|c|c|}
\hline No. & Subjek & $\begin{array}{c}\text { Bentuk } \\
\text { Representasi }\end{array}$ & Indikator & $\begin{array}{c}\text { Soal } \\
\text { Nomor } 1\end{array}$ & $\begin{array}{c}\text { Soal } \\
\text { Nomor } 2 \\
\end{array}$ & $\begin{array}{c}\text { Soal } \\
\text { Nomor } 3 \\
\end{array}$ \\
\hline \multirow{7}{*}{1.} & \multirow{7}{*}{ SA1 } & \multirow{3}{*}{ Verbal } & $\begin{array}{l}\text { Siswa menyusun langkah-langkah } \\
\text { penyelesaian sebuah permsalahan } \\
\text { dalam bentuk verbal }\end{array}$ & $\checkmark$ & $\checkmark$ & $\checkmark$ \\
\hline & & & $\begin{array}{l}\text { Siswa menggunakan representasi } \\
\text { verbal untuk menyelesaikan } \\
\text { permasalahan }\end{array}$ & $\checkmark$ & $\checkmark$ & $\checkmark$ \\
\hline & & & $\begin{array}{l}\text { Siswa menyimpulkan solusi dalam } \\
\text { bentuk tulisan }\end{array}$ & - & - & $\checkmark$ \\
\hline & & \multirow[t]{2}{*}{ Visual } & $\begin{array}{l}\text { Siswa menyajikan kembali data } \\
\text { dalam bentuk visual (berupa } \\
\text { grafik, diagram, tabel, ataupun } \\
\text { gambar) untuk membantu } \\
\text { menyelesaikan permasalahan }\end{array}$ & $\checkmark$ & $\checkmark$ & $\checkmark$ \\
\hline & & & $\begin{array}{l}\text { Siswa menggunakan representasi } \\
\text { visual untuk menyelesaikan dan } \\
\text { menyimpulkan solusi dari masalah } \\
\text { matematika }\end{array}$ & $\checkmark$ & $\checkmark$ & $\checkmark$ \\
\hline & & \multirow{2}{*}{ Simbolik } & $\begin{array}{l}\text { Siswa menyusun model atau } \\
\text { persamaan matematis dari sebuah } \\
\text { permasalahan }\end{array}$ & $\checkmark$ & - & $\checkmark$ \\
\hline & & & $\begin{array}{l}\text { Siswa menyelesaikan } \\
\text { permasalahan yang berkaitan } \\
\text { dengan persamaan matematis }\end{array}$ & - & - & $\checkmark$ \\
\hline \multirow{2}{*}{2.} & \multirow{2}{*}{ SA2 } & \multirow{2}{*}{ Verbal } & $\begin{array}{l}\text { Siswa menyusun langkah-langkah } \\
\text { penyelesaian sebuah permsalahan } \\
\text { dalam bentuk verbal }\end{array}$ & $\checkmark$ & - & $\checkmark$ \\
\hline & & & $\begin{array}{l}\text { Siswa menggunakan representasi } \\
\text { verbal untuk menyelesaikan } \\
\text { permasalahan }\end{array}$ & $\checkmark$ & - & $\checkmark$ \\
\hline
\end{tabular}




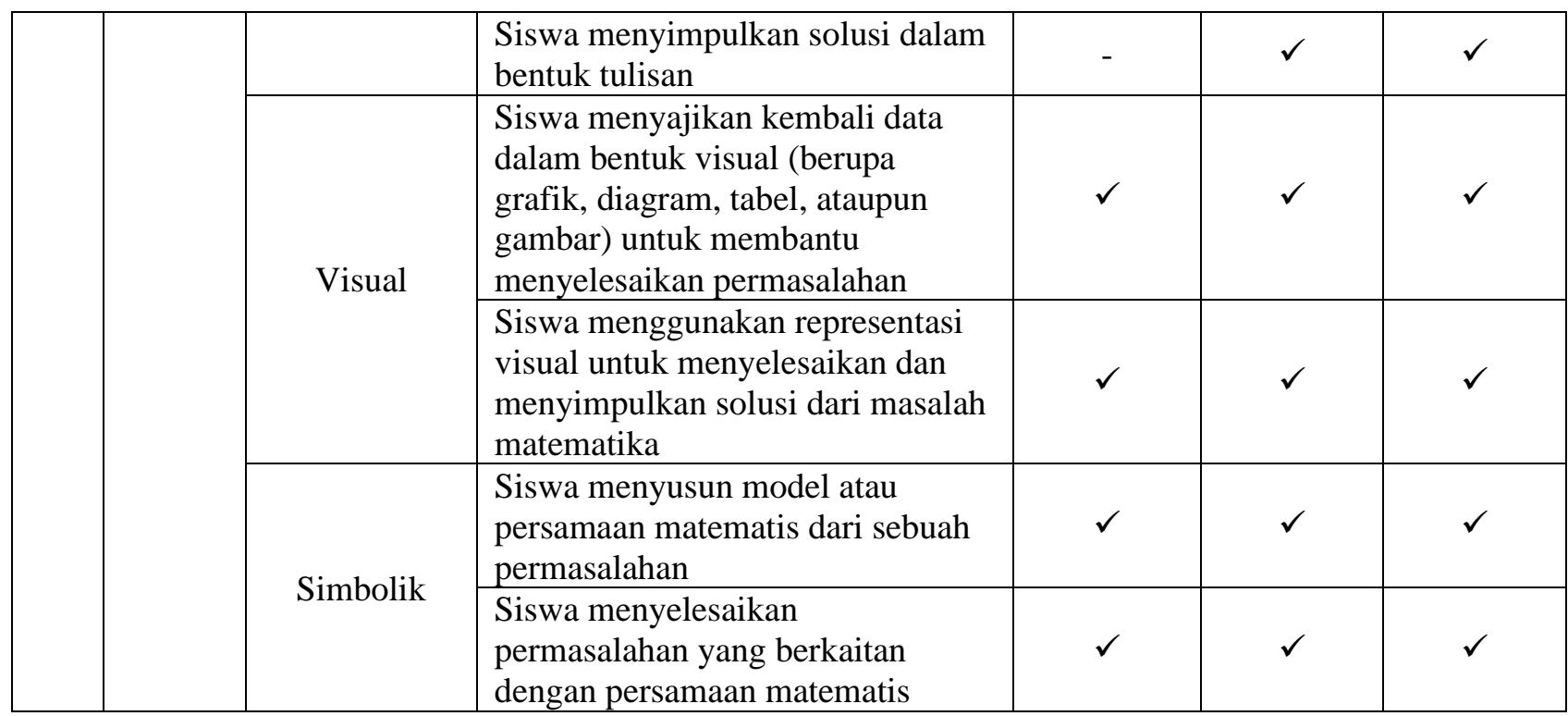

Berdasarkan rangkuman hasil analisis bentuk representasi matematis yang ditampilkan oleh siswa analisis pada tabel diatas, diperoleh kesimpulan jika siswa tingkat analisis dapat menggunakan masing-masing representasi matematis yaitu: verbal, visual, dan simbolik dalam mengerjakan soal. Representasi verbal yang ditampilkan oleh siswa tingkat analisis misalnya siswa mampu menuliskan langkah-langkah penyelesaian soal. Langkah-langkah penyelesaian soal meliputi siswa dapat menuliskan informasi yang diketahui, apa yang ditanyakan oleh soal, langkah-langkah penyelesaian, dan menyimpulkan solusi. Oleh sebab siswa tingkat analisis dapat menuliskan langkah-langkah penyelesaian, maka siswa dapat menyimpulkan solusi. Meskipun ada siswa yang tidak dapat menyimpulkan solusi, misalnya pada soal nomor 1 dan 2. Akan tetapi, siswa masih dapat menuliskan langkah-langkah penyelesaiannya dan memberikan alternatif lain untuk menyimpulkan solusi. Representasi visual yang ditampilkan oleh siswa analisis ditunjukkan dengan siswa dapat menyajikan data ke dalam bentuk gambar secara tepat dan mampu menggunakan gambar untuk membantu menyelesaikan soal. Misalnya pada soal nomor 2, masing-masing subjek siswa analisis memberikan alternatif penyelesaian yang berbeda dengan menggunakan gambar yang telah dibuat. Representasi simbolik yang ditampilkan oleh siswa tingkat analisis ditunjukkan dengan siswa dapat menyusun model atau persamaan matematis dan dapat menyelesaikan permasalahan pada persamaan matematis. Meskipun ada subjek yang tidak dapat menyelesaikan persamaan matematis, tetapi subjek dapat memberikan alternatif persamaan matematis yang lain untuk menyelesaikan soal, misalnya pada soal nomor 2 .

Penelitian ini dilakukan di kelas IXA MTs Negeri 1 Jember yang berjumlah 24 siswa, tetapi pada saat pengambilan data hanya 17 siswa yang mengikuti dikarenakan ada beberapa siswa yang mewakili kejuaraan dan beberapa siswa tidak diperbolehkan hadir ke sekolah. Siswa yang tidak dapat hadir kesekolah, tidak ditindak lanjuti sebagai subjek penelitian. Berdasarkan data yang diperoleh, terdapat 4 siswa ada pada tingkat berpikir visual dan 13 siswa ada pada tingkat analisis. Pengklasifikasian siswa kedalam tingkat berpikir geometri didasarkan lembar kerja siswa pada tes kemampuan berpikir geometri. Tes kemampuan berpikir geometri berjumlah 25 soal berbentuk pilihan ganda yang dikutip dari Sunardi (2000). Setiap 5 soal merepresentasikan seseorang kedalam masing-masing tingkatan berpikir pada teori Van Hiele. Siswa diklasifikasikan berada pada tingkat berpikir visual apabila dapat menjawab dengan benar 3 soal pada tingkat visual dan gugur pada 
tingkat berpikir selanjutnya. Sedangkan siswa diklasifikasikan berada pada tingkat analisis apabila dapat menjawab dengan benar 3 soal pada tingkat visual dan 3 soal pada tingkat analisis.

Pemilihan subjek untuk mengikuti tes representasi matematis materi segiempat dan wawancara didasarkan kepada hasil tes kemampuan berpikir geometri. Setiap masing-masing tingkatan berpikir dipilih 2 subjek berdasarkan rekomendasi dari guru matematika. Subjek yang terpilih dari tingkat visual yaitu siswa dengan kode SV1 dan SV2. Sedangkan subjek yang terpilih dari tingkat analisis yaitu siswa dengan kode SA1 dan SA2.

Berdasarkan hasil analisis data tes soal segiempat dan wawancara, subjek dengan tingkat berpikir visual cenderung menggunakan representasi verbal dan simbolik dalam menyelesaikan soal. Representasi visual yang ditampilkan oleh siswa visual misalnya menyajikan data ke dalam bentuk gambar. Gambar yang disajikan masih sederhana dan tidak diikuti oleh sifat-sifat bangun geoemetri. Apabila diikuti oleh sifat-sifat bangun geometri, misalnya pada soal nomor 1 dan 2, maka siswa kurang tepat dalam menyajikan gambar. Oleh sebab itu, siswa tingkat visual masih belum dapat menerjemahkan data secara tepat ke bentuk visual, misalnya gambar (indikator 1). Subjek pada tingkat visual hanya dapat menggambarkan bangun yang tidak terlalu banyak berhubungan dengan sifat-sifat bangun geometri. Hal ini sesuai dengan penelitian yang dilakukan oleh Sulistiowati et al (2018) dimana siswa pada tingkat visual belum bisa menghubungkan informasi dari objek fisik yang diberikan dan mengembangkannya ke model geometri. Hal ini juga sesuai dengan penelitian yang dilakukan oleh Yildiz et al (2009) yang menyatakan bahwa siswa pada tingkat visual memiliki karakteristik diantaranya yaitu siswa hanya dapat menyelesaikan permasalahan yang tidak terlalu banyak memuat sifat-sifat bangun geometri. Siswa tingkat visual menggunakan representasi verbal dengan menuliskan terlebih dahulu informasi yang diketahui, ditanyakan, dan langkah-langkah cara menjawabnya. Menurut Villages (dalam Feriyanto, 2020) bahwa langkah-langkah tersebut adalah bagian dari representasi verbal. Akan tetapi, subjek pada tingkat visual tidak dapat menuliskan langkah-langkah dalam menjawab soal apabila subjek tidak bisa meyajikan data ke dalam bentuk gambar (indikator 2). Oleh karena tidak dapat menuliskan langkah-langkah dalam menjawab soal, maka tentu saja subjek tidak dapat menyimpulkan solusi dari soal (indikator 3). Hal ini sesuai dengan penelitian Armadan et al (2017) yang menyatakan bahwa siswa pada tingkat visual hanya mampu merepresentasikan gambar geometri untuk menyelesaikan soal dan siswa tidak bisa menyelesaikan permasalahan selanjutnya. Bentuk-bentuk representasi simbolik yang ditampilkan oleh subjek tingkat visual berupa model matematika yang disebut sebagai rumus luas sebuah bangun $a$ dan rumus pythagoras (indikator 1). Model atau persamaan matematis yang digunakan olehsiswa tingkat visual bergantung sekali terhadap gambar yang disajikan. Apabila gambar belum pernah diketahui model atau persamaan matematisnya, maka siswa tingkat visual tidak bisa menyelesaikan soal. Misalnya pada soal nomor 2, siswa visual belum bisa menyajikan data ke dalam bentuk gambar, sehingga soal nomor 2 tidak dapat terselesaikan. Penelitian yang dilakukan oleh Hwang (dalam Rahmadian et al., 2019) menyatakan jika data yang diterjemahkan ke dalam rumus, persamaan atau ekspresi matematis merupakan bagian dari representasi simbolik.

Berdasarkan hasil analisis data tes soal segiempat dan wawancara, subjek dengan tingkat berpikir analisis dapat mengggunakan semua bentuk representasi matematis antara lain: verbal, visual, dan simbolik dalam mengerjakan soal. Hal ini sesuai dengan penelitian yang dilakukan oleh Armadan et al (2017) bahwa semakin tinggi tingkat berpikir siswa, maka siswa akan lebih mudah dan kreatif dalam menyelesaikan masalah matematika yang disajikan dalam bentuk verbal atau kata-kata, visual berupa gambar, dan simbolik berupa ekspresi matematis. Representasi visual yang ditampilkan oleh 
siswa analisis ditunjukkan dengan siswa bisa menyajikan data ke dalam bentuk gambar secara tepat dan mampu menggunakan gambar untuk membantu menyelesaikan soal (indikator 1). Misalnya pada soal nomor 2, masing-masing subjek siswa analisis memberikan alternatif penyelesaian yang berbeda dengan menggunakan gambar yang telah dibuat. Lalu, subjek mengolah gambar untuk membantu menyelesaikan soal (indikator 2). Hal ini sesuai dengan penelitian oleh Sulistiowati et al (2018) yang menyatakan bahwa siswa pada tingkat analisis dapat membuat model geometri berdasarkan informasi yang diketahui. Lalu, representasi simbolik yang ditampilkan siswa tingkat analisis ditunjukkan dengan siswa dapat menyusun model atau persamaan matematis dan bisa menyelesaikan permasalahan pada persamaan matematis (indikator 1 dan 2). Meskipun ada subjek yang tidak dapat menyelesaikan persamaan matematis, tetapi subjek dapat memberikan alternatif persamaan matematis yang lain untuk menyelesaikan soal, misalnya pada soal nomor 2. Hal ini sesuai dengan penelitian oleh Yildiz et al (2009) bahwa siswa pda tingkat analisis dapat menyelesaikan masalahmasalah geometri dengan menggunakan sifat-sifat yang diketahui oleh sebuah bangun.

Pada penelitian ini, tingkat berpikir geometri siswa yang semakin tinggi mempengaruhi representasi yang dimunculkan oleh siswa dalam mengerjakan soal. Siswa dengan tingkat visual cenderung menggunakan representasi verbal dan simbolik. Sedangkan untuk siswa tingkat analisis dapat menggunakan representasi verbal, visual, dan simbolik. Representasi verbal yang ditampilkan oleh siswa visual ditampilkan dengan siswa dapat menyusun langkah-lagkah penyelesaian meliputi informasi apa yang diketahui pada soal, apa yang ditanyakan oleh soal, dan langah-langkah dalam menyelesaika soal (indikator 1). Sedangkan representasi verbal yang ditampilkan oleh siswa analisis yaitu menyusun langkah-langkah penyelesain (indikator 1), menggunakan representasi verbal untuk menyelesaikan masalah (indikator 2), dan menyimpulkan solusi dalam bentuk verbal (indikator 3). Meskipun ada subjek siswa analisis yang tidak dapat menyimpulkan solusi secara tepat, akan tetapi subjek mampu memberikan langkah-lagkah dalam mencari hasil solusi tersebut. Representasi visual yang ditampilkan siswa tingkat visual ditunjukkan dengan siswa mampu menyajikan data ke dalam bentuk gambar (indikator 1). Gambar yang disajikan oleh siswa visual masih sederhana dan tidak memuat sifat-sifat bangun geometri. Hal ini ditunjukkan dengan siswa kurang tepat dalam menyajikan data pada soal nomor 1 dan 2. Sedangkan untuk representasi visual siswa analisis ditunjukkan dengan siswa mampu menyajikan data ke dalam bentuk gambar meskipun diikuti oleh sifat-sifat geometri (indikator 1). Hal ini dapat ditunjukkan dengan siswa dapat menyajikan gambar soal nomor 1, 2, dan 3 secara tepat. Representasi simbolik yang ditampilkan siswa tingkat visual ditunjukkan dengan siswa mampu menyusun model atau persamaan matematis untuk menyelesaikan soal (indikator 1). Model atau persamaan matematis yang disajikan merupakan bentuk umum yang sering dijumpai oleh siswa dan siswa kurang bisa mengembangkan model tersebut. Hal ini ditunjukkan pada soal nomor 1 dimana siswa kesulitan dalam mencari sisi-sisi luasan. Sedangkan representasi simbolik yang ditampilkan oleh siswa analisis ditunjukkan dengan dapat membuat dan mengembangkan model atau persamaan matematis. Meskipun ada subjek yang tidak dapat menyelesaikan persamaan matematis pada soal nomor 2, akan tetapi subjek mampu mengembangkan persamaan matematis baru dari gambar yang ia sajikan. Hal ini sesuai dengan penelitian oleh Armadan et al (2017) bahwa dengan meningkatnya tingkat berpikir siswa, siswa akan lebih kreatif dan mudah dalam menyelesaikan masalah matematika yang disajikan dalam bentuk verbal atau katakata, visual berupa gambar, dan simbolik berupa persamaan matematis.

\section{Kesimpulan}

Berdasarkan hasil analisis dan pembahasan, dapat disimpulkan terkait representasi matematis siswa bina prestasi MTsN 1 Jember dalam menyelesaikan masalah segiempat ditinjau dari level Van Hiele ditunjukkan dengan tabel representasi matematis siswa tingkat visual dan analisis. Representasi 
verbal siswa tingkat visual ditunjukkan dengan siswa mampu menyusun langkah-langkah penyelesaian soal. Langkah-langkah penyelesaian soal yang dituliskan oleh siswa tingkat visual meliputi informasi apa yang diketahui, apa yang ditanyakan oleh soal, dan langkah-langkah penyelesaian soal. Akan tetapi, langkah-langkah penyelesaian soal yang dituliskan siswa visual kurang lengkap, sehingga siswa tidak dapat menyimpulkan solusi. Represetasi verbal siswa tingkat analisis ditunjukkan dengan siswa mampu menyusun langkah-langkah penyelesaian soal. Langkahlangkah penyelesaian soal yang dituliskan oleh siswa analisis meliputi informasi apa yang diketahui, apa yang ditanyakan oleh soal, langkah-langkah penyelesaian, dan solusi dari soal. Langkah-langkah yang dituliskan siswa analisis lebih lengkap dari siswa visual, sehingga siswa mampu menyelesaikan dan menyimpulkan solusi dari soal.

Representasi visual siswa tingkat visual ditunjukkan dengan siswa dapat menyajikan data ke dalam bentuk gambar. Akan tetapi, gambar yang disajikan masih sederhana dan tidak diikuti oleh sifat-sifat bangun geometri. Sifat-sifat bangun geometri diantaranya seperti sumbu putar. Apabila gambar diikuti oleh sifat-sifat bangun geometri, siswa visual kurang tepat dalam menyajikan data ke dalam bentuk visual. Selain itu, siswa tingkat visual tidak dapat menggunakan gambar secara tepat untuk membantu menyelesaikan soal. Representasi visual siswa tingkat analisis ditunjukkan dengan siswa dapat menyajikan data ke dalam bentuk gambar. Gambar-gambar yang disajikan siswa analisis juga telah diikuti sifat-sifat bangun geometri. Selain itu, siswa tingkat analisis dapat menggunakan gambar secara tepat untuk membantu menyelesaikan soal. Siswa analisis mampu mengolah gambar yang telah dibuat untuk membantu menyelesaikan soal, misalnya dengan membagi sebuah bangun menjadi beberapa bagian.

Representasi simbolik siswa tingkat visual ditunjukkan dengan siswa menyusun model atau persamaan matematis untuk menyelesaikan sebuah bangun. Model atau persamaan matematis yang ditulis oleh siswa visual merupakan model yang sering dilihat oleh siswa. Oleh karena itu, representasi simbolik siswa tingkat visual sangat erat kaitannya dengan representasi visual. Apabila gambar belum pernah diketahui model atau persamaan matematisnya, maka siswa visual akan kesulitan dalam menyusun model atau persamaan matematis. Representasi simbolik siswa tingkat analisis ditunjukkan dengan siswa menyusun model atau persamaan matematis untuk menyelesaikan sebuah bangun dan dapat menyelesaikan persamaan tersebut. Subjek tingkat analisis mampu mengolah gambar untuk dicacah menjadi bangun-bangun pecahan yang lain untuk dicari luasannya, sehingga persamaan matematisnya dapat dibuat. Oleh karena itu, siswa tingkat analisis lebih kreatif dalam menyusun model atau persamaan matematis berdasarkan gambar yang telah dibuatnya.

\section{Daftar Pustaka}

Amir, Z., \& Risnawati. (2015). Psikologi Pembelajaran Matematika(First ed.). Yogyakarta: A. Pressindo.

Armadan, Somakim, \& Indaryanti. (2017). Kemampuan Representasi Matematis Siswa pada Pembelajaran Berbasis Teori Van Hiele di Materi Segiempat Kelas VII SMP Negeri 1 Indralaya Utara. Jurnal Elemen, 3(1), 49-57.

Erdo, T., \& Durmu, S. (2009). The Effect of the Instruction Based on Van Hiele Model on the Geometrical Thinking Levels of Preservice Elementary School Teachers. Procedia Social and Behavioral Sciences, 1, 154-159. https://doi.org/10.1016/j.sbspro.2009.01.029

Gafur, M. A., Ismaimuza, D., \& Puluhulawa, I. (2016). Penerapan Pendekatan Saintifik untuk 
Meningkatkan Hasil Belajar Siswa pada Materi Hubungan Sudut Pusat dengan Panjang Busur dan Luas Juring Lingkaran Kelas VIII SMP Negeri 10 Palu. Jurnal Elektronik Pendidikan Matematika Tadulako, 3(06), 427-439.

Kartini. 2009. Peranan Representasi Dalam Pembelajaran Matematika. Seminar Nasional Matematika dan Pendidikan Matematika 2009: 361-371.

Nadjib, A. (2014). Analisis Kesalahan Pemahaman dalam Materi Segiempat Menurut Tingkat Berpikir Van Hiele pada Siswa SMP Negeri 1 Suppa Kabupaten Pinrang. Jurnal Pepatudzu, $8(1), 14-23$.

NCTM. (2000). Six Principles for School Mathematics. Reston VA: NCTM.

Sabirin, M. (2014). Representasi dalam Pembelajaran Matematika. Jurnal Pendidikan Matematika, 01(2), 33-44.

Safrida, L. N., R. Ambarwati, dan E. R. Albirri. (2017). Partisipasi mahasiswa dalam pembelajaran kooperatif berdasarkan lesson partisipasi mahasiswa dalam pembelajaran kooperatif berbasis lesson study ( undergraduate students participation in cooperative learning based on lesson study ). Edukasi. 06(April 2019)

Siswoyo, B. (2012). Peningkatan Hasil Belajar Sifat-Sifat Segiempat dengan Pendekatan STAD ( Student Teams Achievement Divisions ) di Kelas VII-1 SMP Negeri 2 Kutalimbaru. Jurnal Kreano, 2(November), 89-102.

Yıldız, C., Aydın, M., \& Kögce, D. (2009). Comparing the old and new 6 th - 8 th grade mathematics curricula in terms of Van Hiele understanding levels for geometry. 1, 731-736. https://doi.org/10.1016/j.sbspro.2009.01.128 